\title{
COMPARING THE DEVELOPMENT OF BORDER REGIONS WITH THE USE OF GIS (THE CASE OF RUSSIA)
}

\author{
Vladimir Kolosov • Andrei Medvedev • Maria Zotova \\ Institute of Geography \\ Russian Academy of Sciences \\ Staromonetny pereulok 29, 119017 Moscow: Russia \\ e-mails: vladimirkolossov@gmail.com • a.a.medvedeff@gmail.com • zotovam@bk.ru
}

\begin{abstract}
The objective of the paper is to analyze the trends and the dynamics of socio-economic development in the areas on both sides of all Russia's land boundaries (more than 22,000 km long) using remote sensing data and GIS applications at different scales. The originality of this research is in the processing of large amounts of data (30 meters resolution images and medium-scale topographic maps) on vast areas and the construction of maps allowing analyzing the data on a new scale. The peripheral character of most border areas is a serious challenge for the development of cross-border cooperation. Depopulation and the depressed state of their economy do not stimulate contacts between neighboring territories. The authors assess the socio-economic situation on both sides of Russian borders and the contrasts between neighboring territories in the mirror of the structure and the dynamics of land use and the density of settlements and roads. The authors come to the conclusion that the border space experiences further fragmentation. The processes on the 'new' (postSoviet) and 'old' borders differ by their speed and the character of transformations. Their asynchrony is quickly increasing the asymmetry of cross-border interactions.
\end{abstract}

\section{Key words}

borders $\bullet$ remote sensing $\bullet$ spatial analysis $\bullet$ mapping $\bullet$ assessment $\bullet$ socio-economic development $\bullet$ Russia

\section{Introduction}

Two main views or traditions are usually distinguished in borders studies. The first of them is state-centric: it is focused on concrete objective phenomena and interprets boundaries as fundamental elements of international peace and order. The second one, the 'post-modern' tradition is developed on the basis of post-modern philosophy and considers boundaries as a dynamic and multidimensional social construct based on social practices, narratives and symbols (GrundyWarr \& Schofield 2005). At the same time, it is possible to cluster border studies around four dimensions - political, economic, cultural, environmental and regional (Krasteva 2015). The economic dimension includes such issues 
as comparisons of neighbouring territories and their dynamics, complementarity in border regions' resources, their economic structure and specialization, function as filters and barriers in the space of flows, and the role in the territorial organization of adjacent regions and countries.

'Economic' issues have been studied by geographers since a long time. The classic examples of borderlands' comparisons date from the 1930s. Jacques Ancel wrote as early as in 1938: "it is not the frame that is important but what is framed" (Ancel 1938:3). On the background of proliferating studies on boundaries as symbols, their impact on identities' building and political discourse they can seem too traditional and based on old approaches. It partly explains a relatively little attention paid last years to economic problems related with borders. But in the conditions of globalization and economic integration, which gave rise to new issues like cross-border regionalisation, regionalism and de/re-territorialisation, 'traditional' themes are as important as in past.

\section{Borderlands and their cultural landscape: inertia and dynamics}

Only a small share of world international borders can be classified as 'integrating', in terms of Martinez (1994). Most international boundaries continue to function in the Westphalian world and make up a considerable and uneven barrier for various people and goods, and separate different economic, political and legal spaces. The difference between them and the asynchrony in their dynamics determine the direction, the intensity and the composition of cross-border flows.

In his classical studies of Silesian borders Hartshorne $(1933,1936)$ emphasized the importance of a boundary's 'age' which plays a considerable role in shaping the local cultural landscape ${ }^{1}$. He suggested distinguishing

\footnotetext{
1 Landscape and in particular cultural landscape belong to key notions in geography but it are interpreted in a very different ways depending on the traditions of national geographical schools, sub-discipline and
}

between the borders that have been allocated before the formation of the cultural landscape that he called antecedent, and those that divided the already existing landscape ('subsequent borders'). In case when the borders completely ignore cultural landscape they can be classified as superimposed. Hartshorne paid a particular attention to the sensitivity of the territorial organization of society and land-use to borders' dynamics. Later J.R.V. Prescott (1987) proposed a matrix helping to analyze the reciprocal influence of different natural and social elements of cultural landscape: relief, hydrography, land-use, etc.

Russia represents a particularly instructive and at the same time difficult case for comparative border studies because it has land boundaries with 16 states - more than any country of the world. It means that the country is facing a wide variety of political, economic, cultural and environmental challenges related with neighbourhood with very different countries - from Norway to North Korea. Natural conditions, the level of social and economic development, the structure of economy, and cultural features of population living along both sides of the border are extremely diverse.

The collapse of the Soviet Union created new state boundaries between former union republics dividing cultural landscapes developed within the same country for centuries. Post-Soviet borders considerably differ from the borders delimited long ago, as a result of World War Two or even earlier (Kolosov 2011). Border landscapes can serve good markers indicating the features and the distinctions in economic, political and legal space of neighbouring countries, reflect securitization policy and other sides of the state's impact on economic and social activity. Borders are certainly an element of 'slow geography' as compared with the spatial patterns of flows and geography communications ('fast geography').

other factors (Dell'Agnese 2015). R. Hartshorne understood it as a synonymous of cultural region. We follow here this interpretation. 
Minghi (1963) showed that a basic property of a boundary is inertia. It explains the phenomenon of phantom borders defined as political and cultural borders which politically or legally do not exist anymore, or lost their most important functions, or lost/changed their meaning but appear in different forms and modes of economic, social and political activity today (von Hirschhausen et al. 2015). Such borders can remain visible in cultural landscapes for centuries like, for instance, the borders between Western Ukraine, formerly part of the Austro-Hungarian Empire, and the rest of this country or between the parts of Poland included after its partition into the Austro-Hungarian and Russian empires, and Prussia.

'Traditional' themes like the impact of the boundary's dividing function on cultural landscapes can be now studied not only by the methods of comparative statistical analysis but from the perspective of new, 'post-modern' approaches. Economic gaps separating neighbouring countries and regions can be critically important in the processes of 'othering' and 'b/ordering' (van Houtum \& van Naerssen 2002) and in shaping or maintaining nation$\mathrm{al} /$ ethnic identity and the feeling of superiority. They fill the territories with meaning (Tamminen 2004): rich and poor, North and South, order and chaos, good and evil, us and them. They mirror the relations between neighbours - a changing combination of conflict, competition, subordination and cooperation, as well as the different aspects of the border's perception. Boundaries maintain the economic competition and the territorial division of labour, allow comparing the efficiency of production in different countries, and the ethnic and cultural variety of the world. Neighbourhood involves permanent comparisons between 'here' and 'there', and border identities can shift under rapidly-changing economic circumstances, especially in light of perceived improvements in quality of life (Kolosov \& O'Loughlin 1998; Kolosov 2005). The relation between the border location and peripheral position is not linear, and the boundaries' can change a centreperiphery relation (Moracheveskaya 2010).
The objective of this paper is three-fold: firstly, to analyze the difference in cultural landscape on both sides of Russian land borders and its dynamics; secondly, to consider the influence of new borders emerged as a result of the disintegration of the Soviet Union on the differentiation of formerly similar landscapes; thirdly, testing the methods of remote sensing and spatial analysis in studying vast border spaces on various scales. The authors analyze the trends and the dynamics of cultural landscapes in the areas on both sides of all Russia's land boundaries $(22,125 \mathrm{~km}$ long) and compare the situation in 'old' and 'new' borderlands using remote sensing data and GIS technologies with the functions of spatial analysis, GIS modeling (geo-modeling) and cartographic visualization.

\section{Data and methods}

Modern border studies show a need for the simultaneous use of traditional and relatively new approaches and a clear shift from special to interdisciplinary researches. Border location can be considered as a challenge to the development of borderlands that creates limitations and additional problems, but also as an opportunity to use the benefits of cross-border location, which requires a special regional policy. Various research methods are used for studying border processes.

Mapping is one of the oldest approaches in border studies. But there is a dramatic gap between border studies and cartography. Borders' mapping is one of the least developed areas of cartography. Countries and regions are presented on many maps as 'islands' which do not have neighbors. These fixed and static images create a wrong picture. Moreover, maps are rarely used as a tool of analysis, though the development of GIS and remote sensing allows considerable innovations in border mapping (Kolosov \& Tikunov 2005). They can be divided into three types: (1) development of new approaches to old themes; (2) creation of maps on new, previously unknown topics; (3) use of GIS mapping and remote sensing data. 
Maps of borders' morphology - a traditional theme of border maps - can serve an example of the first type of innovations. Such maps can show the degree of borders' coincidence with natural boundaries, their 'age' and origin, the differences in socio-economic indicators between neighboring regions. The second type of innovations consists in mapping gravitation of population, cities and human activities around borders, cross-border socio-economic and integrated social-natural systems, the conformity of the state borders to ethnic boundaries, and the real barrier functions of different borders' sections in terms of their crossing's costs. The complementarity of borderlands' resources, the potential for cross-border cooperation, strategies and initiatives, natural reserves and other protected cross-border environmental systems, the role of borders in ethnic and other conflicts, the asynchrony of social and economic development on different sides of the border, and securitization of borders and their symbolic value can be also considered as new themes of mapping.

The third kind of innovations is the use of GIS mapping methods, including spatial analysis and remote sensing data. A relevant objective is mapping of border areas on different scales proper to the character of international, national, regional and local problems related with boundaries. The multi-scale approach to spatial data on different dates gives a key to the understanding of local social processes. Integration of multi-scale data allows solving the problems provoked by an uneven availability of data and bringing them to a compatible form despite of fragmentation and heterogeneity of materials, and the medium and high spatial resolution in case of remote sensing data. Spatial analysis tools based on GIS software helps to process data covering large territories and to interpolate them on different scales for further analysis. GIS techniques are also used in the analysis on road accessibility in the studies on borderlands (Więckowski et al. 2014). Remote sensing data and the results of their automated and semi-automated processing give a qualitative representation about a territory, its development, the use of resources and the state of environment. In addition, remote sensing data are an objective, independent source for a retrospective analysis.

A comparative study puts a number of problems for statistical analysis: the discrepancy in statistical variables used in different countries, the divergence in their meaning and collection's methods; the difference and the change in the administrative-territorial division, and the size of territorial units, etc. Indicators expressed in natural values and remote sensing showing, for instance, the 'objective' dynamics of land use or of settlements' size allow partially avoiding these problems.

However, border mapping raises similar questions, especially the incompatibility of scales series used in standard topographic maps in different countries and the classification of different objects important for generalization. The authors suggest a way to solve or bypass them in applying GIS technologies. We selected the change in land use, precisely in the extension of non-cultivated lands and forest areas, and the density of roads and settlements as indicators of socio-economic dynamics. They show whether social processes on both sides of the boundary go in the same or the opposite direction and reveal their range and impact.

GIS technologies were used for assessing cross-border disparities between border regions of Russia and neighboring countries and their dynamics. GIS technologies were applied, firstly, to the processing of remote sensing information and, secondly, in spatial analysis of basic spatial data.

Multi-temporal satellite images ${ }^{2}$ and the results of their further classification served the main source of information on the types of land cover. Operations with satellite images based on advanced geometric processing

\footnotetext{
${ }^{2}$ Seamless mosaics of satellite images obtained by processing the 'raw' remote sensing data from different imaging devices and systems: Global Land Cover 2000, mosaic created at the University of Maryland (UMD); series and sets of classified satellite images of Landsat system 5/7/8, available on Geoportal USGS.
} 
(the reduction to the accepted system of spatial coordinates) were conducted according to the following scheme:

- visual interpretation of images in order to identify objects on the key and reference sections (elimination of uncertainties). Visual decoding was conducted on the basis of ready mosaic of high and ultra-high spatial resolution images $(1-10 \mathrm{~m})$ offered by web mapping services Yandex, GoogleMaps, BingMaps (Microsoft), ArcGIS.Imagery (ESRI), Roscosmos Geoportal. Visual methods were applied for decoding in order to select correct references for automatized interpretation and verification of the results of automated processing;

- automatized decoding of images (classification, quantization of brightness, calculation of statistical information) made it possible to process images of $30 \mathrm{~m}$ resolution for extended border sections. A combination of automatized decoding with a visual analysis simplified and speeded up the process;

- controlled classification of multispectral images for creating a training sample. Objects' recognition put serious difficulties. Indeed, cultivated and uncultivated lands are extremely heterogeneous and have different spectral properties in different combinations. This problem was solved by using the method of maximum likelihood based on a probabilistic approach;

- generalization of raster data, automatic vectorization and editing of results; visual update based on indirect characteristics (association, neighborhood, etc.) together with editing in a vector format. GIS mapping supposes a resizing of raster cells, the change of its resolution for enlarging the raster graduation in accordance with the scale of the study. The operation consists in establishing the size of new cells and recalculating the average arithmetic value of original raster cells. The result is a natural coarsening of the original layer.

This work allowed mapping the change in border cultural landscapes in 2000-2010. We selected three key elements of cultural landscapes: density of settlements, density of road networks and land use (the extension of recently abandoned arable lands and deforestation). This choice was determined by information that can be received from both remote sensing and topographic maps. We opted for an analysis of all road network including also dirt roads, though most cross-border traffic passes by the highways between major cities: firstly, because in some border areas there are simply very few hard surface roads, especially crossing the border; secondly, because the network of hard surface roads is often fragmented: a section in good condition follows a broken segment, and a dirt road in an area with sandy soils can be better than a road which is officially considered as a hard surface one. Finally and most importantly, the density of all roads is a mirror of economic activity and their pattern makes up a premise for cross-border contacts on the municipal level and the creation of local crossing points destined for the inhabitants of the nearest localities.

Satellite images provide reliable information on land use in distinguishing between cultivated and non-cultivated lands and between forest vegetation and the areas of felling. But decoding images on the forest-steppe and steppe zones does not give a satisfactory result because of an important error provoked by ta large extension of the areas with oppressed vegetation or without it. Therefore, the method was not applied to the RussianKazakhstani border.

The methods of spatial analysis were applied to basic data from the topographic maps at the scale of $1: 200,000$ and $1: 100,000$ on the zone of $50 \mathrm{~km}$. Vectorization of roads and settlements consisted in digitalization of their outlines on topographic maps. After that, information from the original source of data was attributed to every object. Information on certain borders' sections was updated from the service Open Street Map (OSM). Further operations included processing of data in order to create regular grids with $1 \times 1 \mathrm{~km}$ cells for showing the density distribution for linear and dot objects. Each cell corresponds to the density at the respective point 
(cell) of the area. Program modules Spatial Analyst - PointDensity and LineDensity of ArcGIS were used for this purpose.

The originality of this methodology lies in the processing of large amounts of data (30 meter resolution images and mediumscale topographic maps) on vast areas (several thousand square kilometers) and the construction of maps which allow analyzing the data on a new scale. Maps of roads and settlements networks as well as maps of deforestation and land use in the border areas indicate developing and depressive areas, to compare neighbouring areas and to assess the disparities between them.

\section{Differentiation of 'old' and 'new' Russian borderland}

For a more detailed analysis we selected five cases at different sections of 'old' and 'new' Russian borderlands situated in various natural, historical and social conditions along the boundaries: (a) with Finland; (b) with Estonia and Latvia; (c) with Belorussia and Ukraine, (d) with Kazakhstan and (e) with China.

The Russian-Finnish borderland is in general an area with sparse population and rare network of settlements. However, on the Finnish side the density of settlements is significantly lower (Fig. 1), with the exception of the area around Lappeenranta (about 72,000 inhabitants) and Imatra, a twin city of Russian Svetlogorsk, a former suburb of Imatra located in only $5 \mathrm{~km}$, and the area of Joensuu. All northern part of the Russian-Finnish borderland is very scarcely populated but there are relatively more settlements on the Russian side. Most of them are rather small. But there are some towns situated not far from the boundary. The most important of them is Kostomuksha in $30 \mathrm{~km}$ from the boundary which has about 30,000 inhabitants. It was built near an iron ore mine and a big plant which processes it. Another town, Kovdor, also emerged near an iron ore deposit, just at the limit of the $50 \mathrm{~km}$ zone. A higher density of settlements on the Russian side as compared with the Finnish border zone is a result of Soviet policy consisted in building selfsufficient permanent settlements even in the north, instead of exploiting natural resources by camp-type operations.

Despite of a thicker network of settlements, the density of roads on the Russian side is incomparably rarer even in the more populated southern part (Fig. 2). Only close outskirts of Saint Petersburg, the second largest city of Russia, can compete in this regard with southern provinces of Finland. The road network in Finnish border areas has a different structure: it is continuous, and not divided into a number of separated 'trees' connected with the main axis of communications in depth of the state territory. Post-Soviet Russia did not get rid of the fundamental handicap inherited from the past - weak infrastructure.

The contrasts in land use are also significant and partially caused by the different availability of infrastructure (Fig. 3). On the Russian side, logging was much more territorially concentrated because of the scarcity of roads and the irregularity of their pattern. A wider distribution of thinning is also hampered by economic reasons, in particularly, low productivity, insufficient wood processing facilities and its low depth, and the bankruptcy of some pulp and paper mills (PPM) in the 1990s. In the early 2000s deforestation concerned the areas close to the existing timber processing plants and in general the southern part of the boundary with Finland, one of the main destinations of Russian export of round timber.

The territorial pattern of forestry on the Russian side closely depends on the proximity of Finnish PPM and the boundary. In the Republic of Karelia forestry works mostly for the Finnish market. The share of Russia in the Finnish timber import exceeds $70 \%$. In addition, the price of raw material in Finland is significantly higher and it is more profitable to export Karelian wood abroad than to deliver it to local plants (Karvinen et al. 2011; Belâev \& Martynov 2015). Cooperation with Finnish partners is asymmetric and contradicts the interests of Russian border regions, as timber is sold 'on the stump' and Karelia 

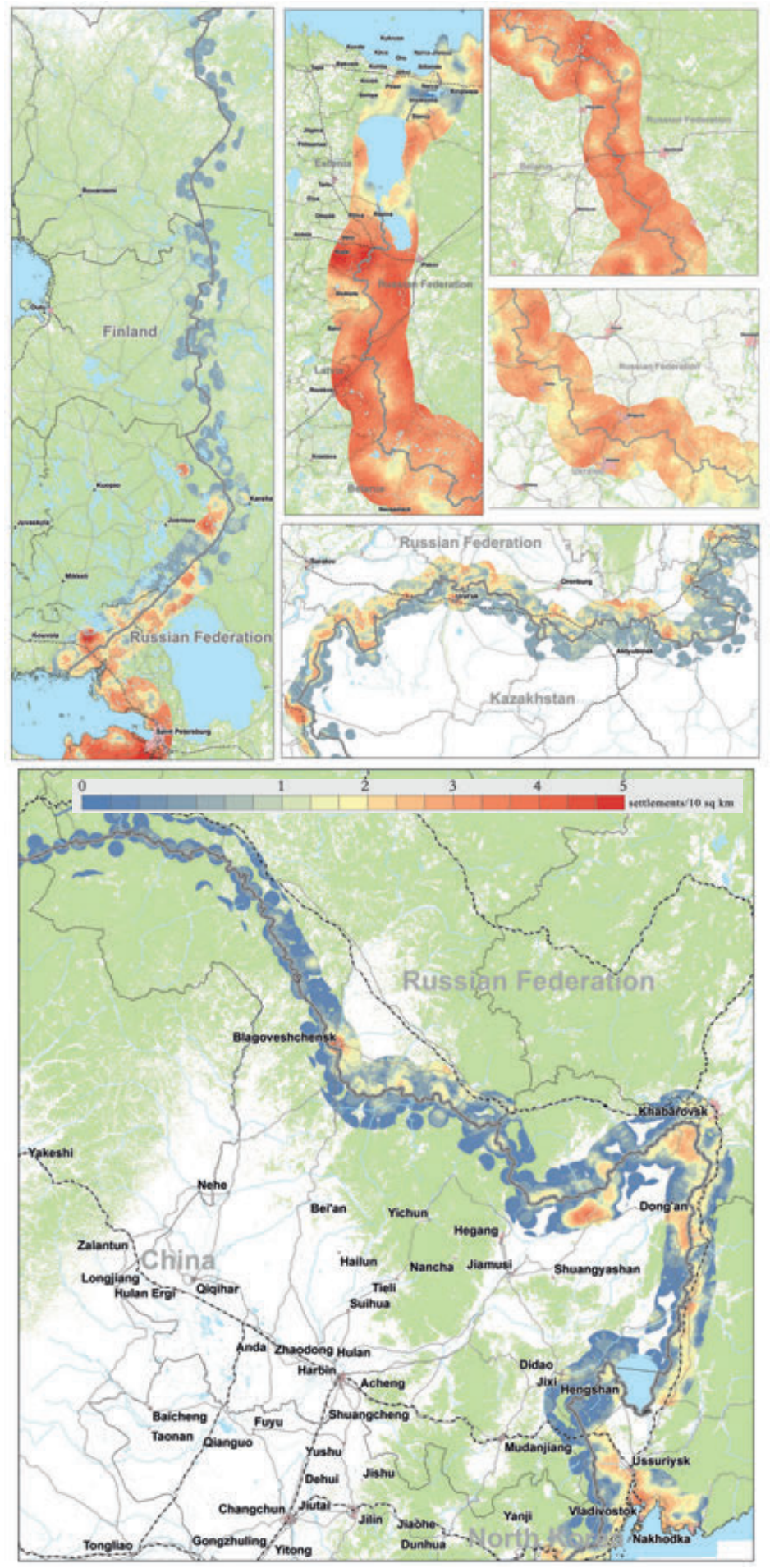

Figure 1. Density of settlements in Russian borderlands 
receives only a small so-called 'stump fee' from 6 to 11 US dollars per cubic meter of timber. On their turn, Finnish timber enterprises which use their own loggers prefer to work near the boundary, and not in the 'internal' areas of Karelia, saving on transport costs (Cyplenkov 2014).

On the Finnish part, the territorial dispersion of logging is much higher. A more rational organization of forestry and its better control by the state in combination with a higher density of roads made possible a more balanced distribution of cutting areas. Sanitary felling on more than 300 thousand hectares provides a large part of timber (in Karelia it embraced only 50 thousand hectares) (Lesovodstvennaâ i èkonomičeskaâ ... 2014).

Distinctions in the patterns of logging are also explained by different regulation more stringent in Russia: protection zones where cutting is totally prohibited embrace the areas 50-200 m large from rivers, and $50 \mathrm{~m}$ - along lakes, while in Finland some general recommendations concern only the strip of about 10-20 m. The maps show that there were no cuts on the Russian side in water protection areas, while in Finland it was possible.

In Russian Karelia cutting in the zone along the boundary was strictly forbidden. However, in 1995 the government allowed
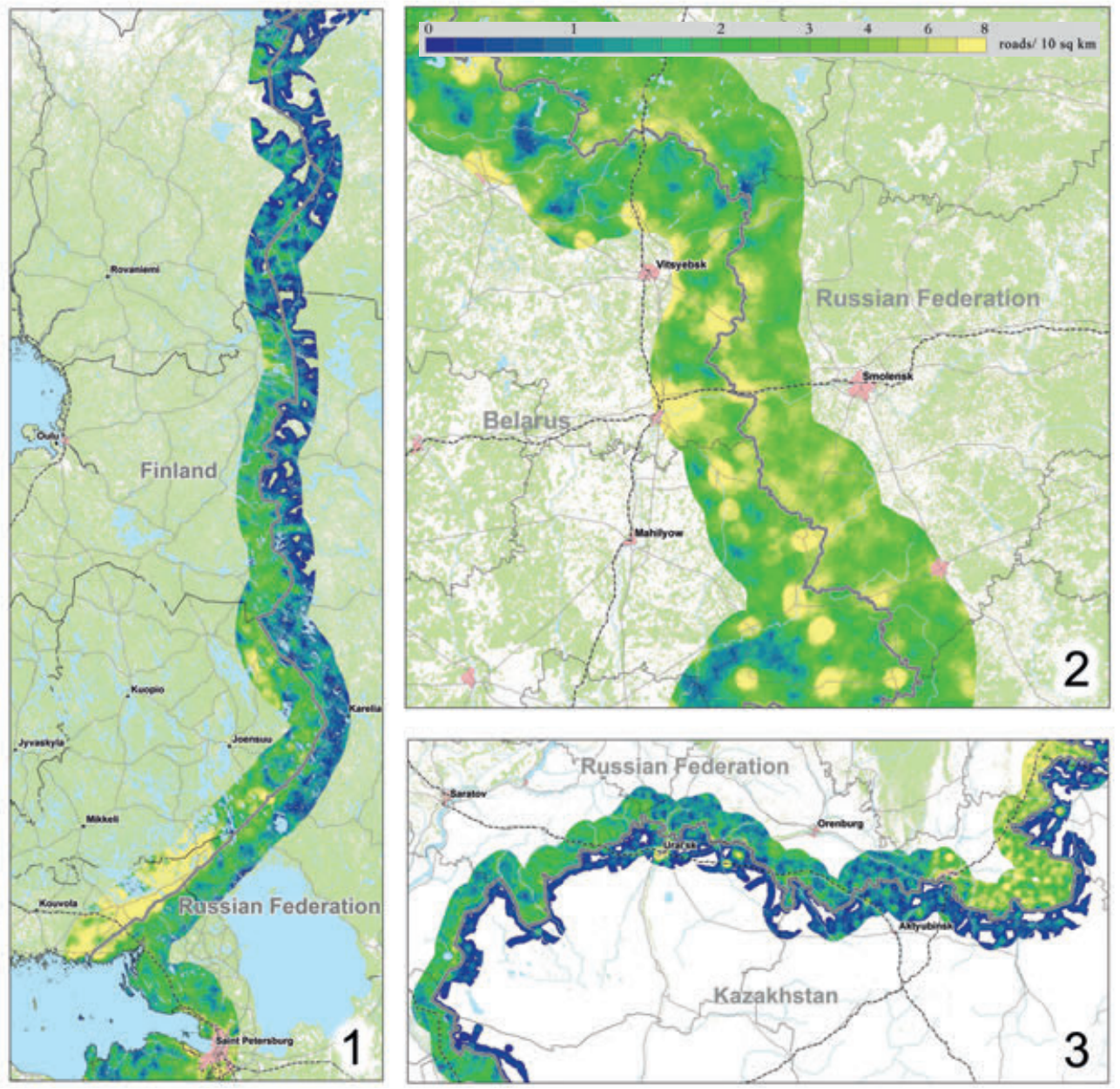

Figure 2. Density of roads in Russian borderlands 

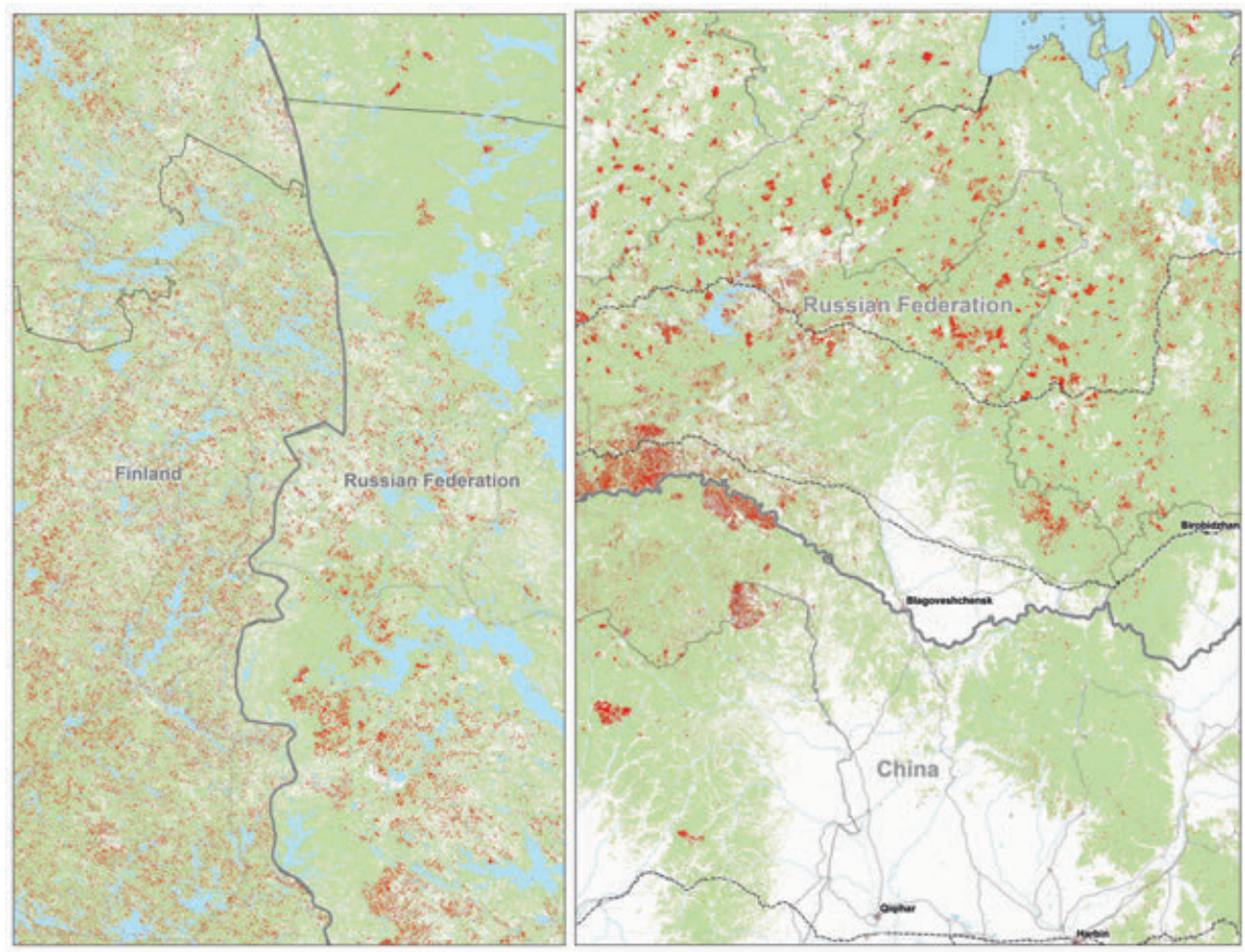

Figure 3. Deforestation in Russian borderlands (2000-2010): red areas are the areas of deforestation

felling a million cubic meters of wood per year in the two-kilometer border zone (Karel'skaâ regional'naâ ... 2010). Since that time forest is cut down in some areas close to the boundary (Kalevala, Sortavala districts, Kostomuksha urban district) for export to Finland. But in general this two-kilometer strip is still weakly affected by felling.

In the vicinity of Saint Petersburg, especially on the coasts of the lake of Ladoga, deforestation was also caused by the construction of second homes.

In case of the borderland with Estonia and Latvia the contrasts are very noticeable. A higher concentration of settlements on the Estonian side around Võru is due to the remnants of the traditional small farmstead settlement system while on the Russian side a similar system was much more destroyed by Soviet collectivization. The density of roads in Estonia is higher than in Russian and Latvian borderlands, particularly around Ivangorod and
Narva. The first of these twin cities is a small town with less than 11,000, while Narva counts about 62,000 inhabitants.

Like Finland, Baltic countries also widely use thinning and sanitary felling. In Latvia, the intensity of the thinning over the past 20 years has increased by $34 \%$. Better forest management explains a more even territorial distribution of felling in comparison with border regions of Russia. At the same time, in 2000 there were much more abandoned agricultural lands in Estonian and Latvian border areas than on the Russian side (Fig. 4). After the collapse of the Soviet Union and privatization of the agro-industrial complex Latvia had in 2005 the highest ratio of non-used agricultural lands in Europe (27.6\%). Their quality was not directly related with their use. In Latvia and Estonia medium and high-quality lands often became abandoned because of problems with ownership, an insufficient size of plots, bad location, etc. 

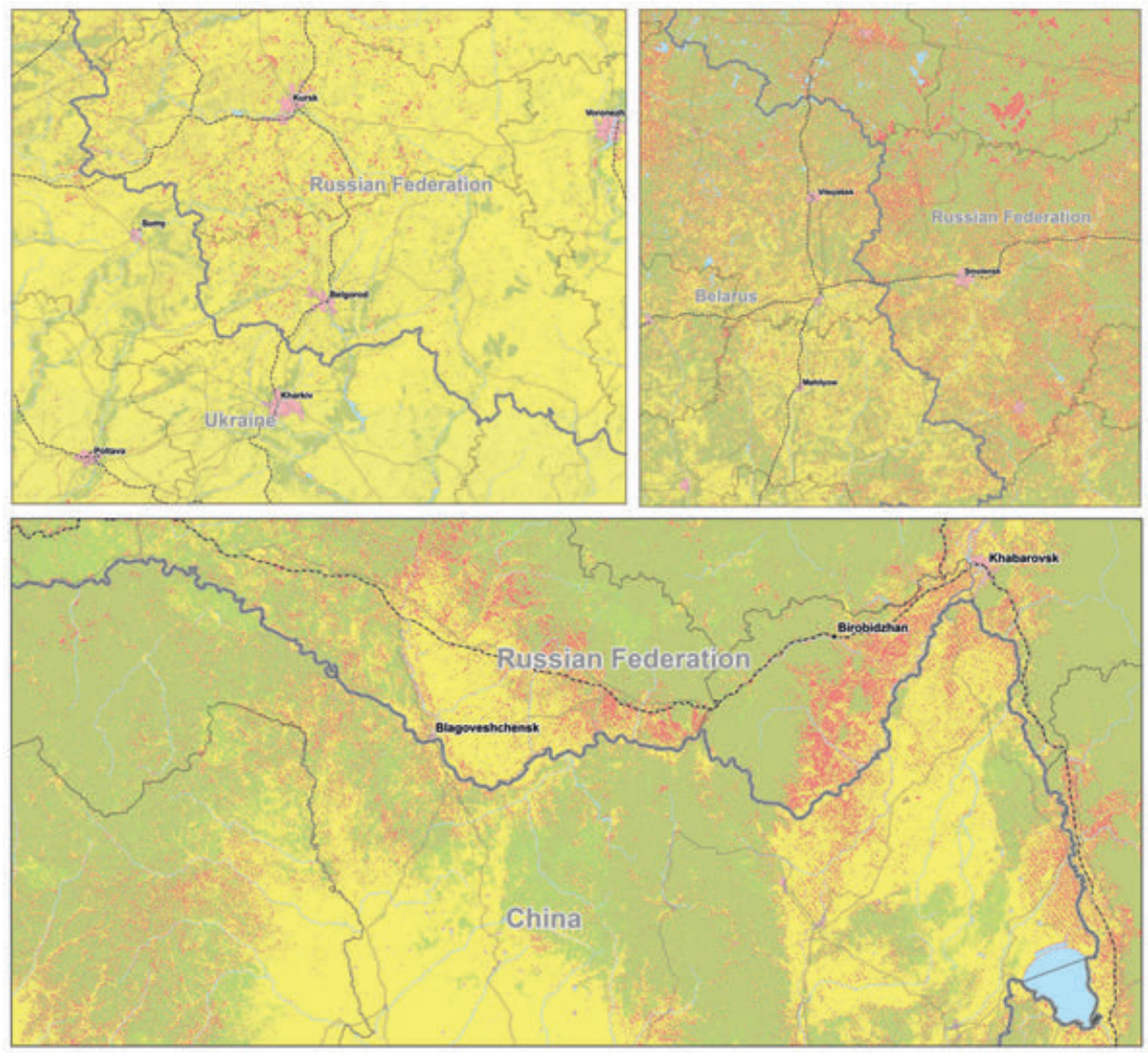

Figure 4. Abandoned agricultural lands in Russian agricultural lands (2000-2010): yellow areas show cultivated lands, red areas - abandoned cultivated lands

(Alcantara et al. 2013; Zabrošennye... 2013). However, by 2010 their agriculture adapted to new conditions: a part of abandoned lands was reintroduced into use. On the contrary, in neighboring Pskov region, one of the poorest in Russia, the surface of abandoned lands grew up as a result of depopulation, the lack of human capital and low productivity.

The contrasts in the borderland with Belorussia and the central-northern part of the border with Ukraine are determined by the settlement system and centre-periphery structures. On their turn, they are related with natural conditions - the pattern of watersheds, hydrography, etc. The Russian-Belorussian section is characterized by a greater density of settlements than the Russian-Ukrainian one but villages in the forest zone are smaller. It is higher in the vicinity of important cities and along the main axis of communication, especially Saint-Petersburg - Nevel - Vitebsk - Orsha - Kiev - Odessa and Moscow - Smolensk - Orsha - Minsk - Warsaw. Particularly visible are the premises for the formation of an agglomeration between Kharkiv, the second largest city of Ukraine with the population of more than 1.5 million, and Belgorod, the centre of a successful and relatively healthy region of Russia, situated at less than $70 \mathrm{~km}$ from each other (Kolosov \& Vendina 2011). Unfortunately, this perspective is postponed for a long time as a result of political conflict.

It can be noticed that in the northern part of the borderland with Ukraine the density 
of settlements is most often higher on the Russian side which reflects a better performance of agriculture and higher incomes. The density of roads follows this pattern. It is higher on the Russian side and near large cities - Kharkiv, Polotsk, Sumy and Orsha.

No considerable change in land use is observed between 2000 and 2010 on the Belorussian and Ukrainian sides of the boundary, while on the Russian side the share of abandoned arable lands increased, particularly in the districts located far from the main cities and in the areas with less favourable soils and other natural conditions. The change in the surface of arable lands is not directly related with the productivity of agriculture. Their shrinking on the Russian side (Smolensk region) is in a sharp contrast with Belorussia and results from a rapid and continuing depopulation, the decline of the countryside and a depressive state of most "Non-Black soils" regions. It shows that the state of rural territories depends on human capital and social reasons in general rather than on the agro-climatic potential. On the Belorussian side, in the same natural conditions the lands are more fertile, and agriculture remains productive (Morachevskaya 2010; Katrovskij \& Kovalev 2012).

At the same time, despite of the decrease of arable lands, Belgorod is one of the leading Russian agricultural regions: it runs the first in the production of pork and chicken and the second in the productivity of cereal crops. In terms of agricultural production per hectare it was significantly more efficient than neighbouring Ukrainian regions.

The Russian-Kazakhstani borderland is much less populated than western regions. There are almost no settlements within the $50 \mathrm{~km}$ strip along the sections of the boundary crossing arid and semi-desert areas. The map shows that the main railway between Central Russia, the Middle Volga (Saratov) and Central Asia (Tashkent) connects all important cities on both sides of the boundary and crosses it twice. Such picture is also proper to other parts of the border: two branches of the Transsiberian (they merge near Novosibirsk) pass by the Kazakhstani territory via Petropavlovsk but nevertheless belong to the state-owned company Russian Railways. On the contrary, a long section on the Russian territory via lletsk (Orenburg region) is run by the company Kazakhstan Temir Zholy, and passengers are subject to passports' control though the station is not located at the boundary (Thorez 2011). In the times of Russian Empire railways were designed to connect the settlements along the internal boundary which separated properly Russian regions with the territories of Kazakhs' wandering (Golunov 2005; Chibilev 2011). Some towns and other settlements were founded on the Kazakh side as local administrative and trade centers.

However, the density of settlements is most often higher on the Russian side, with the exception of the surroundings important $\mathrm{Ka}$ zakhstani cities. This discrepancy is explained by historical reasons. The administrative boundary between Russian regions and Kazakh territories represented a typical frontier gradually moving southward. Its locations are marked by the lines of settlements which used to be fortresses and fortifications settled sometimes by Cossacks ${ }^{3}$ but often with ethnically mixed population. The first lines stretched along the rivers were created in the 18th century, and their parts were connected by earth shafts, ditches, palings, etc. These lines protected properly Russian lands form nomads' incursions and served a basis for colonization either by Russian and Ukrainian Cossaks', or by Russian peasants, who escaped from serfdom, as well as by non-Russian groups (Christianized Tatars, etc.). For security reasons and for avoiding smuggling these spontaneous migrants were allowed settling not closer than $40 \mathrm{~km}$ from the boundary. This rule explains the linear pattern of villages. With time fortifications lost their defensive role, and new lines appeared to the south of them.

The density of roads is also higher on the Russian side; in some areas of Western

\footnotetext{
${ }^{3}$ Members of autonomous semi-military communities, soldiers and at the same time farmers, who lived in sparsely populated borderlands and protected them.
} 
Kazakhstan there are almost no roads at all. The only exceptions are the areas of Uralsk, a former centre of colonization with predominantly Russian-Cossack and Tatar population, nowadays the centre of a region situated not far from the boundary, and another regional centre of Aktobe. The gas field near the town of Aksai on the Kazakhstani side can also be distinguished on the map by a higher density of roads.

Paradoxically, the density of settlements and roads along the boundary with China is in general higher on the Russian side, though the density of population is incomparably lower: only 4.6 inhabitants per square kilometer in the Jewish Autonomous Region, 1.6 - in Khabarovsk territory and about 11 - in the Maritime territory but 89 in the province of Heilongjiang and 146 - in the province of Jilin. The reason is that the most important Chinese cities are located beyond the $50 \mathrm{~km}$ border zone, while in Russia population gravitates around the Transsiberian railway along the boundary. Russian rural settlements are smaller than on the Chinese side. However, there are long sections of the border, especially in its western part, where there is no much difference between Russian and Chinese border areas.

The spatial pattern of abandoned and fallow arable lands has considerably changed between 2000 and 2010. In general, there are more abandoned lands on the Russian side. Agricultural production in the Far East has never fully covered local needs despite of depopulation in the post-Soviet time, while neighbouring Chinese provinces are among the main national producers of such agricultural goods as cereals, meat and milk. The surface of arable lands makes up about 5 million hectares in Jilin and 11 million in Heilongjiang (about 15\% in China). Jilin is the leading province by the livestock of cattle. A specific feature of agriculture in this part of the country is a big role of large companies in the production of meat and milk.

On the Russian side, an obvious trend to the concentration of arable lands in the most fertile areas and their better use can be observed as compared with 2000, particularly in the central part of the Amur region and on the plain around the lake of Khanka, north from the city of Ussuriisk in the Maritime region. Much less lands are now cultivated on agricultural 'islands' in the Far-Eastern taiga - in the northern part and in peripheral and swampy areas. In the depopulated Jewish Autonomous region most former arable lands are not used anymore. In total, the contrasts between two sides of the boundary became more visible.

The areas of massive deforestation are located mainly on the Russian side, in clusters stretched along the boundary, mostly in its western part (Amur region). Forests suitable for harvesting of wood are concentrated in more populated areas. Most of these forests are already in use since a long time, and their resources are partially settled (Rysin 2013).

Illegal cuts undermining forest resources are obviously more frequent in border districts. According to the WWF experts' estimations, more than a half of timber exported from Russia to China has an illegal or doubtful origin. This situation is caused by a number of economic, social and legal factors: the lack of rational forest management and sufficient capacities for their efficient processing, low payment for resources (used by the state for their restoration), the opacity of relations between stakeholders and the imperfection of legislation, etc. Week control of timber industry by the state and the quickly growing demand for timber in China leads to the degradation of the most valuable forests and the loss of the most appreciated biological species (Rossijsko-kitajskoe ... 2010).

On the Chinese side, on the contrary, the state policy of the forest use became stricter. After the 1998 floods cuts along the main rivers and in the north-eastern part of the country are forbidden for 50 years. As a result, the part of import in the domestic timber consumption increased from $10 \%$ in 2008 to $49 \%$ in 2013. Chinese government plans to refuse from cutting natural forests and to switch to the use of plantations woods (Azarin 2010). It increases the demand for timber import from Russia. 


\section{Discussion and conclusions}

The use of remote sensing data and spatial analysis allowed "diagnosing" the situation at different sections of borders. The combination of different data provided new information not only on qualitative and quantitative characteristics of different borders but also gives a new understanding of underlying bordering's processes. It helps to assess the relation between contact and barrier functions at each pair of boundaries. Remote sensing can also be used to monitor, for example, fluctuations of cross-border traffic and the queues at crossing points. Of course, remote sensing by itself is not enough for understanding the dynamic nature of bordering, especially its non-material factors such as identities and social representations about the neighboring country, and the role of institutions, for instance, border regime. But in combination with other methods it shows the way and offers valuable materials for studying economic processes and the social situation on both sides of the border underlying cross-border interactions, like the condition of forestry in Russian Far East.

A study of Russian boundaries and the dynamics of land use in 2000-2010 revealed considerable fragmentation of borderlands at all scales. These gaps are particularly strong at 'old' borders existing since the Soviet or even empyreal time (the case of Finland and China). At 'new' borders dividing Russia and post-Soviet states the differentiation is not so visible and is often explained by historical reasons and territorial patterns shaped well before the transformation of administrative boundaries into lines of separation between independent countries. The density of settlements and roads is naturally more inertial than land use depending more closely on state policy and regulation in different fields.

Borders continue to shape cultural landscapes because of asynchrony and asymmetry of economic and political development on their different sides. The change in the extent of abandoned arable lands in Estonia and Latvia, on the one hand, and Russia, on another hand, showed that in only one decade the asynchrony of economic and social processes changed the picture. In other words, different components of border cultural landscapes have their own specific spacetime patterns.

In Russia with its extremely long boundaries and scarce population 'border' is most often synonymous of 'peripheral' and 'isolated'. The proximity to a border and peripheral location are mutually enhancing factors. They accelerate the departure of economically active people. The increase in border contrasts is to a great extent provoked by strong depopulation of northern and eastern regions of Russia. It particularly concerned remote border areas, in particular, along the borders with Finland and China. On its turn, depopulation leads to the in-ward re-orientation of borderlands' economy, especially of the regions along 'new' borders with Baltic states, Belorussia and Ukraine which have been only recently parts of the single economic space. Fading economy of some border regions matches the general tendency to the 'compression' of Russian space, i.e. increasing concentration of the country's economic potential and population in capital regions and large cities.

The peripheral location of most border areas, the shrinking of rural settlements', roads' network and agricultural lands, and low accessibility is a serious challenge for regional development and cross-border cooperation. In the eastern part Russia, striking contrasts are observed in the land use and the density of population on the opposite banks of the Amur separating Russia and China. On the Chinese side, croplands cover almost all territory in the eastern and central parts of the Heilongjiang province, while on the Russian side taiga still dominates and settlements are rare. But the rates of deforestation stimulated by a high demand for timber in China are rather high, especially along the boundary.

However, the maps compiled on the basis of remote sensing images show a number of relatively dynamic twin-cities, potential 
areas of regional integration and axes of development along major roads. Cross-border interactions are to the growing extent concentrated on few major roads and the most important crossing points. Field studies in twin towns at the Russian border with Finland and China, and in the Kaliningrad exclave showed that everyday cross-border interactions became an intrinsic part of local life and did not diminish much as a result of the current complicated geopolitical situation and unfavourable currency exchange rates. The need in cross-border cooperation with EU countries and regional integration in the Eurasian

\section{References}

Alcantara C., Kuemmerle T., Baumann M., Braglna E.V., Griffiths B., Hostert P., Knorn J., Müller D., Prishchepov A.V., Schierhorn F., 2013. Mapping the extent of abandoned farmland in Central and Eastern Europe using MODIS time series satellite data. Environmental Research Letters, vol. 8, no. 3, http://iopscience.iop.org/ article/10.1088/1748-9326/8/3/035035/meta [12 December 2016].

AnCel J., 1938. Géographie des frontières. Paris: Gallimard.

AzArin A., 2010. Hèjlunczjan i Czilin': issledovanie vozmožnostej po organizacii biznesa $i$ investirovaniû v prigraničnyh s Rossiej provincijah SeveroVostočnogo Kitaâ. General Consulate of Russian Federation in Shenyang, http://rcsy.org/documents/research.pdf [5 Decmeber 2016].

BelÂeV I., Martynov V., 2015. Udarit' berezoi po Finlandii. http://www.svoboda.org/content/article/27118120.html. [10 July 2015].

Cyplenkov S., 2014. The farewell with Russian forest. Priroda - veliky genii. http://biogeniy.ru/archives/867. 30.04.2014 [1 March 2016].

Chibilev A.A. (ed.), 2011. Rossijsko-Kazahstanskij transgraničnyj region: istorija, geoèkologija i ustojčivoe razvitie. Ekaterinburg: Urals Regional Branch of Russian Academy of Sciences.

Dell'Agnese E., 2015. New geo-graphies of border(land)-scapes [in:] C. Brambilla, J. Laine, J.W. Scott, G. Bocchi (eds.), Borderscaping:
Economic Union increase the importance of these areas.

\section{Acknowledgements}

The authors thank Russian Science Foundation for supporting the project "Russian Borders: Challenges of Neighbourhood" (grant No. 14-18-03621) which allowed them conducting this study.

Editors' note:

Unless otherwise stated, the sources of tables and figures are the authors', on the basis of their own research.

Imaginations and practices of border making. Franham: Ashgate, pp. 53-64.

Golunov S.V., 2005. Rossijsko-kazahstanskaâ granica: Problemy bezopasnosti i meždunarodnogo sotrudničestva.Volgograd: Izdatel'stvo VolGU.

Grundy-Warr C., Schofield C., 2005. Reflections on the relevance of classic approaches and contemporary priorities in boundary studies. Geopolitics, vol. 10, no. 4, pp. 650-662.

HARTSHORNE R., 1933. Geographic and political boundaries in Upper Silesia. Annals of the Association of American Geographers, vol. 23, no. 4, pp. 195-228.

HARTSHORNE R., 1936. Suggestions on the terminology of political boundaries, titles and abstracts of papers. Annals of the Association of American Geographers, vol. 26, no. 1, pp. 38-39.

KareL'SKAÂ REGIONAL'NAÂ OBŜESTVENNAÂ ORGANIZACIÂ “AsSociaciÂ ZelenYH KarelII", 07.04. 2010. http:// www.ladoga-park.ru/a 100409123735.html. [5 March 2015].

Karvinen S., Välkky E., Gerasimov Y., DobrovolSKY A., 2011. Northwest Russian forest sector in a nutshell. Sastamala: Vammalan kirjapaino.

KatrovskiJ A.P., Kovalev Ju.P. (eds.), 2012. Rossijskobelorusskoe prigraniče: dvadcat' let peremen. Smolensk: Smolenskij gumanitarnyj universitet.

Kolosov V., O'Loughuin J., 1998. New borders for new world orders: Territorialities at the fin-desiecle. GeoJournal, vol. 44, no. 3, pp. 259-273. 
Kolosov V., 2005., Border studies: Changing perspectives and theoretical approaches. Geopolitics, vol. 4, no. 10, pp. 1-27.

Kolosov V., 2011. Post-Soviet boundaries: Territoriality, identity, security, circulation [in:] D. WastlWalter (ed.), The Ashgate Research Companion to Border Studies Farnham, UK: Ashgate, pp. 171-194.

Kolosov V., Tikunov V.S., 2005. Politikogeografičeskoe kartografirovanie i geoinformatika: Dostiženiâ i novye zadači. Izvestia RAN, seriâ geografičeskaâ, 1, pp. 17-23.

Kolosov V., Vendina O.I. (eds.), 2011. Rossijskoukrainskoe pogranič'e: dvadcat' let razdelennogo edinstva. Moskva: Novyj chronograf.

KRASTEVA A., 2015. Spaces, lines, borders: Imagineries and images [in:] C. Brambilla, J. Laine, J.W. Scott, G. Bocchi (eds.), Borderscaping: Imaginations and practices of border making, Franham: Ashgate. pp. 11-26.

LESOVODSTVENNAÂ | ÈKONOMIČESKAÂ ÈFFEKTIVNOST' RUBOK UHODA ZA LESOM, 2015. Russian State Agricultural University, http://www.activestudy. info/lesovodstvennaya-i-ekonomicheskaya-effektivnost-rubok-uxoda-za-lesom [3 March 2016].

Martinez O., 1994. Border people: Life and society in the US-Mexico borderlands. Tucson: University of Arizona Press.

MINGHI J., 1963. Boundary studies in political geography. Annals of the Association of American Geographers, vol. 53, no. 3, pp. 15-30.

MORACHEVSKAYA K.A., 2010. Prigraničnost' i perifeiinost' kak factory sotsialno-ekonomičeskogo razvitia prigraničnykh c Belorussiei raionov Rossii. Regionalnye issledovania, vol. 4, no. 30, pp. 61-69.

PrESCOT J.R.V., 1987. Political frontiers and boundaries. London: Allen and Unwin.

ROSSIJSKO-KITAUSKOE VZAIMODEJSTVIE: TORGOVLJA LESOMATERIALAMI S KitAEM I nelegal'NYE RUBKI, 2010. http://www.wwf.ru/about/what_we_do/forests/ curbing-illegal-logging/russia-china [1 March 2016].

RYSIN L.P., 2013. Monitoring dinamiki lesov rossijskogo Dal'nego Vostoka. V Vserossijskaâ konferenciâ "Lesa rossijskogo Dal'nego Vostoka". Vladivostok, 18-20 sentjabrja 2012 g. Lesovednie, no. 4, pp. 68-71.

TAMminen T., 2004. Cross-border cooperation in southern Balkans: Local, national or European identity politics? Southeast European and Black Sea Studies, vol. 4, no. 3, pp. 399-418.

ThoreZ J., 2011. Les nouvelles frontières de l'Asie centrale : États, nations et régions en recomposition. Cybergeo: European Journal of Geography, http://cybergeo.revues.org/23707 [10 November 2016].

Van Houtum H., Van Naerssen T., 2002. Bordering, ordering and othering. Tijdschrift voor Economische en Sociale Geografie, vol. 93, no. 2, pp. 125-136.

von Hirschhausen B., Grandits H., Kraft C., MülLer D., SerRIer T., 2015. Phantomgrenzen. Räume und Akteure in der Zeit neu denken. Göttingen: Wallstein Verlag.

Więckowski M., Michniak D., BednarekSzczepańska M., Chrenka B, Ira V., Komornicki T., Rosik P., Stępiak M., Szekely V., ŚlesZYŃSKI P., ŚWIĄTEK D., WIŚNIEWSKI R., 2014. Road accessibility to tourist destinations of the Polish-Slovak borderland: 2010-2030 prediction and planning. Geographia Polonica, vol. 87, no. 1, pp. 5-26.

Zabrošennye sel'hozugod'Â $\vee$ Central'noj I VostoČnOJ EVROPE, 31.12.2013. http://www.agritimes.ru/news/13399/zabroshennye-selhozugodya-v-centralnoj-i-vostochnoj-evrope/\#sthash. N980ovMO.dpuf [5 March 2016]. 